\title{
8. The changing world of work and labour market institutions in India Kingshuk Sarkar
}

\subsection{INTRODUCTION}

During the last decade and half, India has witnessed significant changes in the world of work. There has been large-scale informalization of the labour force (93 per cent being the share of informal labour) (Government of India, 2015) and a corresponding growth in non-standard employment, a decline in social dialogue and tripartism, a weakening of trade unions, and a shift in focus from enforcement of labour laws to redistribution through various social security schemes. During the same time period, India has experienced considerable reforms in labour administration as well as labour legislation. Such reform initiatives have included increasing use of technology, greater focus on skill development and employment generation, introduction of social security and welfare schemes, and amendments of certain provisions of labour laws. In the process, the role of labour administration in India has undergone transformations which are administrative in nature and, unlike in earlier periods, not an outcome of rigorous social dialogue and tripartite consultation processes. A weakening of trade unions across the sectors and across States has further aggravated the situation (Sen Gupta, 2003). A unilateral administrative approach to reforms of labour administration have somewhat diluted the characteristics of 'labour' in labour administration in India. A State vis-à-vis citizen client relation has already replaced the erstwhile tripartite structure (State-Employer-Employee) based on redistribution in an environment of stagnating labour market regime.

This chapter will examine these issues affecting labour administration in India. In doing so, the chapter addresses two questions: how have regulatory institutions in India changed over time and with what consequences; and how have developments in the international organization of production and State action influenced the regulatory environment? 


\subsection{BACKGROUND AND CONTEXT}

India has a federal system of governance. Both Central and State Governments have the power to enact legislations and formulate programmes for the betterment of working and living conditions of the workforce in the country. For all issues relating to the organized and unorganized sector, the Ministry of Labour \& Employment is the nodal Ministry at the Central level. Similarly, there are Labour Departments at the State level looking after the interests of the workers.

India experienced a period of strong economic growth in the 2000s and this has continued to a certain extent. But the situation in the labour market was paradoxical. Data suggested that employment growth was meagre and consequently this period was described as a period of 'jobless growth' (Alessandrini, 2019). Moreover, most of the new jobs created in India were informal, either in the unorganized sector or even in the formal sector, as a result of the rise of contract labour and other forms of non-standard employment (Mehrotra et al., 2012).

Since the process of liberalization started in 1991, India has been undergoing structural transformation through a shift of labour and overall economic activity out of agriculture and into manufacturing and service sectors. In the successful developing countries in East Asia in the second half of the 20th century and earlier in the West during the industrial revolution, that shift was accompanied by rapid job creation in manufacturing. However, in India and in a number of other middle-income countries, the growth of manufacturing has not followed that path. Manufacturing globally has become more capital and skill intensive and this is true even in India where labour is abundant. Even though the contribution of the primary sector towards GDP fell to 15 per cent in 2014-15, the primary sector still provides livelihood options to about 45 per cent of the working population. In India, occupational transformation did not match sectoral transformation (Venkatanarayan and Suresh, 2013).

In India in 2011-12, approximately 92 per cent of Indian workers were in the informal economy, which can be broken down into 82.7 per cent of workers in the unorganized sector and 9.3 per cent of workers who were in the organized sector but informal, in the sense that they lacked access to social security and many other labour market protections (Labour Bureau, Ministry of Labour \& Employment, Government of India, 2015). The increase in total informal employment in recent years is largely due to the growing use of contract labour and outsourcing of production. The use of contract labour is not limited to the private sector but is also growing in the public sector (Rajeev, 2010). Importantly, measures have been adopted to reach out to the informal sector which was previously largely beyond the scope of labour administration. Relatedly, attempts have been made to improve protection for contingent 
labour and workers in the internet-enabled on-demand economy. However, the labour administration system in India is complex, with labour inspection services at both the national and State level, which makes coordination of inspection services a challenging one.

\subsection{FLEXIBILITY IN THE LABOUR MARKET AND LABOUR ADMINISTRATION}

The Indian legal framework is old and fragmented. Some activities are heavily regulated while others lack even the basic protections. There is considerable scope for a reform process which could create a more contemporary comprehensive regulatory framework comparable to those that are being practised in some other G20 and BRICS countries. The need for reform of the labour market in India has been forcefully articulated since the 1990s. Industry and business interests, the corporate media and a section of economists have repeatedly complained about the so-called rigidity in the labour market in India, alleging that protective legislations have made retrenchment of workers and closure of industry difficult. ${ }^{1}$ However, the so-called rigidities associated with labour laws coexist with an increasing degree of flexibility stemming from three major sources. First, labour laws have been progressively relaxed by the States like Gujarat, Madhya Pradesh, Rajasthan, Haryana, Andhra Pradesh, Uttar Pradesh and others. Labour laws have also been interpreted liberally in recent years by courts in favour of employers. Second, the implementation of these laws has been very poor because of lack of political will as well as a weak implementing machinery. Third, in order to keep down labour costs and acquire greater flexibility, employers have been able to systematically re-engineer labour and employment relations in manufacturing through outsourcing, sub-contracting, splitting production facilities and refashioning employment relations in the factories. Many firms have been able to re-engineer their workforce to engage a small 'core' workforce comprising regular workers and a much larger proportion of temporary and highly flexible peripheral workforce. The peripheral workforce consists of both contract labourers and other temporary workers, including trainees and apprentices. Downsizing in firms has mainly related to permanent workers who are subsequently replaced by casual/contract workers, most of whom work round the year (and are referred to as 'permanent temps').

If the law is to permit engagement of workers on more flexible terms in the form of easier dismissal, then there is a need to ensure an appropriate degree of severance compensation. The Supreme Court in some of its recent judgments opined that the conditions of service of contract labourers should be on a par with those of regular workers. Labour contracts will need to build in possibilities for improvements over time, both in terms of employment and income security. This will require a new and more credible compact between the State, 
employers and workers leading to changes which are based on social dialogue and broad-based consensus. A number of academics have criticized the relative lack of social dialogue, as well as the continuing weakness of employment rights and protections (Papola and Pais, 2007).

\subsection{INFORMALIZATION OF THE LABOUR FORCE AND LABOUR ADMINISTRATION}

If labour administration focuses its efforts only on the formal economy, large numbers of workers and employers will fall outside its protection and influence. Therefore, labour administration needs to adopt a much wider perspective that addresses the needs of all workers and employers in both formal and informal sectors. One important question is how to extend labour administration services (and labour inspection in particular) to the informal economy.

In 2014, the total labour force of India amounted to 406 million workers. Around 397 million of these individuals were in work, yet barely 28 million were employed in the organized sector. Approximately 369 million workers (around 93 per cent of the total) were in the unorganized sector. About 237 million workers were employed in agricultural and related activities, 17 million in construction, 41 million in manufacturing, 37 million in the service sector and the remaining 37 million in trade. The share of the unorganized sector in total GDP at current prices has been over 60 per cent in recent years, while the household sector has tended to account for approximately 75 per cent of GDP (Labour Bureau, Ministry of Labour \& Employment, Government of India, 2015). This shows the significance of the informal sector in the economy.

India is a large country both in terms of workforce in the unorganized sector and the geographical area over which it is spread. The unorganized sector workers are engaged in numerous occupations from their residential premises or small work sheds employing one or two workers or even entire families. Under such circumstances, the enforcement machinery of the Central and State Governments cannot reach every part of the country and labour administration bodies therefore have to consider alternatives to the existing labour enforcement mechanism. Local bodies, voluntary organizations, non-governmental organizations (NGOs) and trade unions can potentially be assigned a larger role in this regard.

Over the past 15 years, some specific laws for the unorganized sector have been enacted by the Central government, and also some States. They have benefited building and construction workers, inter-State migrants, agricultural labourers, beedi workers and transport workers among others. For example, there are Acts that empower the government at both national and State levels to establish special funds to provide social security benefits to workers by imposing a tax (or cess) on the aggregate output of selected industries. The 
Beedi Workers' Welfare Fund is a national fund that is constituted from a tax on beedis (hand-rolled cigarettes). There are similar welfare funds at the State level, such as the Head loaders'2 Fund in Gujarat and Maharashtra, to which employers pay a levy. Tripartite boards ${ }^{3}$ administer them in some States and labour administration bodies play a significant role in monitoring their effective functioning. The social assistance benefits and services under these welfare funds include housing allowances, school scholarships, death benefits, maternity assistance and health benefits. The funds are designed to overcome the difficulties caused by the absence of a clear employer-employee relationship and to redistribute some of the profits of the industry among the workforce.

Most of the existing labour laws do not apply to workers in the informal sector. One way of extending the laws would be to relax applicability clauses relating to the number of workers employed in a particular establishment. For example, the Factories Act 1948 becomes applicable if a factory employs a minimum of 10 workers (with the aid of electricity) or 20 workers (without the aid of electricity). Thus, for many small factories in the informal sector, this Act is not applicable. The implication is that for social protection and social security to be extended to informal sector workers, labour legislation must be made universally applicable irrespective of number of workers employed at each individual unit. There are cases in which this has happened. In particular amendments were made in 2010 to the Employees' Provident Fund Act and Employees State Insurance Act so as to extend their provisions to workers in unorganized sectors. Certain new labour laws are also being developed to incorporate different groups of informal sector workers, such as domestic workers. A draft Domestic Workers Bill has been prepared which, if passed, will (among other things) facilitate domestic workers' registration as workers promote their rights to organize and form their own association, promote skills development (with entry points to professionalization and wage increases), establish mechanisms to protect the rights of domestic workers who seek work abroad, raise public awareness of domestic work as a legitimate labour market activity and place an obligation on household employers to provide minimum wages and decent working conditions to domestic workers. However, this Bill is still under consideration and has yet to become an Act.

Of all those who work in the informal sector, 52 per cent are self-employed (Government of India, 2015). It is very difficult for labour administration bodies to reach these self-employed workers since traditionally the scope of intervention by the labour administration is limited to workplaces where there is an employer-employee relationship. But in the case of a self-employed person, employment relationships do not exist and self-employed persons are therefore outside the purview of the national labour administration system. Furthermore, many activities are now being outsourced to people who work at 
their home through arrangements akin to the 'putting out' system. No formal contracts are established in respect of such work, which is undeclared and these workers are unprotected. To address this kind of exclusion, labour administration needs to look beyond employer-employee relationships and focus on the idea of work and service provider. Even in the case of wage employments, a vast majority of informal sector workers continue to lack social security coverage. In this regard, labour administration has its own limitations, such as a lack of staff and inspectors and a lack of infrastructure to cater to the large number of informal sector workers. Lack of awareness among the informal sector workforce further worsens the problem.

\subsection{INCLUSION AND REDISTRIBUTION MECHANISM}

Indian labour administration, both at Central and State levels, has tried to incorporate the informal sector into its activities in two ways. First, through better implementation of those Acts which are applicable to the informal sector, such as the Minimum Wages Act 1948. A sizable number of workers in the informal sector are engaged in agricultural activities where the only labour legislation that is applicable is the Minimum Wages Act 1948. Apart from this, the Payment of Wages Act 1936, Contract Labour Act 1970, Inter-State Migrant Workmen's Act 1979, Building and Other Construction Workers Welfare Act 1996 are examples of a small number of other Acts that provide legal and social protection to the informal sector labour. Second, boards have been created to provide social security and welfare facilities to workers in the informal sector, including those in self-employment. Some of these boards are statutory in nature while others operate at the State level. They are mostly State-funded but certain schemes are also financed through a cess specifically collected for the purpose. Workers' dependents/family members are included in the social security schemes. In order to register for a scheme, eligible workers must submit documents to prove their identity and professional attachments along with photographs. Once the beneficiary registration officer is satisfied that the applicant is a genuine worker in the respective occupation, he or she is registered under the scheme/act and accordingly provided with an identity card/passbook. At the time of registration, the beneficiary needs to pay a registration fee (e.g. Rs30) along with an initial contribution. Certain social security schemes, such as that for building and other construction workers, require the registration of enterprises, which must apply and pay a fee. This type of scheme is prevalent in cases where a cess is applicable and is intended to help reduce the extent of informalization.

Employers' organizations are represented on welfare boards as part of tripartite conventions, but they are generally passive participants in the process. 
Workers' organization, by contrast, actively participate in the boards created for inclusion of informal sector labour and they initiate discussions in board meeting and pressure the government for greater inclusion of informal sector workers within the ambit of labour administration.

While the boards have proved to be a relatively effective means of redistribution, enforcement of applicable labour laws continues to be problematic because of various limitations affecting the enforcement authorities and the fact that a majority of the workers in the informal sector (52 per cent) are self-employed. Although labour inspectors have the right to investigate suspected cases of false self-employment, in practice it is very difficult to take remedial action as there are normally layers of intermediaries which create ambiguity and camouflage employment relationships. These intermediaries are rent-seekers and do not add any value; rather they create distortions. The State is supposed to be administrator of these social security schemes and targeted beneficiaries are supposed to directly approach the State in order to receive benefits. However, because of a lack of awareness, apathy and inability to complete certain paperwork (making application in prescribed form, submitting necessary documents and photographs, getting necessary certificate regarding occupation etc.), intermediaries are able to exploit vulnerable potential beneficiaries (Sarkar, 2016) and siphon-off benefits intended for workers. Intermediaries even make bogus claims on behalf of workers who are ineligible. For instance, in the State of West Bengal, three million beneficiaries are registered under the construction workers' welfare scheme, but many of these individuals are not even construction workers (Sarkar, 2018). Thus, there is a need to eliminate intermediaries as far as possible so as to establish a direct link between the State and the beneficiaries. That will prevent leakage of financial resources and benefit the genuine beneficiaries.

A further difficulty is that various social security schemes are currently being run by different Ministries/Departments and agencies at the State level, with different eligibility criteria, enrolment criteria and benefits. This requires an unorganized worker to approach different government agencies and departments for registration. The beneficiary also faces challenges in availing themselves of the benefits of the schemes. In addition, many workers are unaware of entitlements, benefits and their eligibility for various schemes and the process and documentation for registration and grievance redressal mechanisms under these schemes (Singh, Sanyal, and Bharati, 2015).

To reach out to the informal sector, Labour Departments in the Centre and within States have tried to reform their bureaucratic structures. For example, in West Bengal, the activities of labour administration have been decentralized to the level of Blocks ${ }^{4}$ in the form of Labour Welfare facilitation Centre (LWFC). Inspectors are now being posted at these centres so that informal sector workers have someone to assist them in joining a social security scheme. 


\subsection{INDUSTRIAL RELATIONS}

Indian industrial relations have been built on a complex set of engagements among the employer, the government and the trade unions, who have often adopted strategies which are more reactive than proactive. After India achieved independence in 1947, the State continued to play a direct and dominant role in regulating industrial relations by legislative process. ${ }^{5}$ The number of unions grew substantially after independence and their proliferation has been a distinguishing feature of the trade union history in India since independence. Unions are mostly concentrated in the organized sector and thus a very large majority of Indian workers do not belong to any trade union. Many workers in the private sector in particular are not covered by any dispute resolving mechanism. The growth of the informal sector, along with the decline of manufacturing, has eroded the strength of trade unions further. Much of the support for trade unions has traditionally come from the manufacturing sector and from employees of public sector organizations. Trade union density has declined globally during the past two decades and India is no exception. Major central unions in India are affiliated to mainstream political parties and certain activities of these trade unions are influenced by political considerations rather than pure labour interests. Data show that membership of such politically affiliated trade unions declined during the last two decades. General union membership fell from 6.9 million in 1990 to 5.3 million in 2000. The fall in union membership has been more pronounced in manufacturing, where union membership fell from 2.3 million to 1.2 million during the same period (Srivastava, 2006). These trade unions are increasingly finding it difficult to mobilize workers. Workers find less relevance in their unions being driven by an agenda set by political parties. Increasingly, it is the enterprise-based rather than industry or national-level unions which appear to appeal to workers. The new generation of younger workers prefers to concentrate on specific issues and problems reflecting their immediate work context, working conditions and compensation. At the same time, national trade unions which are mostly identified with mainstream political parties are also facing a dilemma - whether to follow political compulsions or to respond to the conditions of the workers which are confined to boundaries of enterprises (Dhal, 2018). At the same time, relatively new industries either do not have trade unions or have trade unions that are unit based, without being affiliated to central trade unions related to mainstream political formations. To safeguard their relevance, unions are trying to redefine their structures and role.

Industrial disputes resolution processes in India have suffered from excessive delays, formalism and inaccessibility and the mechanism has not been sufficient to check incidences of unfair labour practices by employers. 
Furthermore, the number of industrial disputes reaching tripartite conciliation machinery is showing a gradual decline. That does not necessarily imply that the number of cases of industrial dispute has been declining but that the ability of trade unions to press for conciliation has been shrinking. Trade unions are experiencing weakening bargaining power, primarily because of a global restructuring of production processes. The power of labour in the post-globalization phase has therefore been declining even without significant change in the legal framework. This is further corroborated by the rising incidence of person-days lost due to lockouts rather than because of strikes (Sen Gupta and Sett, 2000).

There is an increasing tendency on the part of employers to try to weaken trade unions so as to promote organizational flexibility and competitiveness. One device used to dilute legal protections for workers is to re-designate their jobs so as to take them out of the ambit of the protection of the Industrial Dispute Act 1947. The new designations that are being used include officers, junior executives, supervisors and so on. Under the law, only legally defined workmen have access to legislative protection and other categories do not have such access or protection. In addition, many employers have engaged in 'corporate paternalism' as a means of discouraging unionization of their employees. Jindal Aluminium Ltd in Bangalore, for example, has successfully followed such policies (Patil, 1998).

\subsection{INTERNAL ORGANIZATION AND COORDINATION}

Both the Centre and the State can legislate on labour matters, although in cases where jurisdictions overlap, the Centre will prevail. However, the jurisdictions of the Centre are limited to workers employed by establishments that are run by the Centre. Other workers, including those in the private sector and in the informal sector, are the responsibility of the respective State governments. Overall, 90 per cent of workers come under the purview of States. Thus, while both Centre and State have their respective administrative machinery in place throughout the country, jurisdictions are separate and clearly demarcated. There exists an ecosystem of Centre-State dialogue that facilitates discussion on all important labour issues. Before any new initiatives, such as new enactments or amendments, the Centre mandatorily convenes discussions with all State departments. Issues are discussed and the perspectives of States are taken into account as part of the policy formulation process. However, such an ecosystem is lacking with respect to State-to-State dialogue, which has become more important given that an increasing number of workers are migrating across States in search of livelihoods. With respect to Centre-State coordination, there are problematic issues, such as the existence of separate minimum 
wages relating to similar types of employment, and similar issues that do not have clear solutions and where jurisdictions are unclear to workers.

Labour administration machinery has itself become weak over the years. Half of the posts of the inspectors are vacant at the time of writing (2018) in the Centre and the States. During the last 20 years, the number of inspectors in Delhi has fallen from 100 to nine. Because of the shortage of inspectors, each inspector has to cover a greater area and take on a larger number of tasks, resulting in capacities that are severely compromised. Further, there is lack of coordination between the different wings of labour administration; any attempt to include the informal sector requires a concerted effort among the involved institutions, but there is no platform that might ensure inter-institutional coordination. Nevertheless, labour administration bodies at both Centre and State levels seek cooperation from other government departments as their own activities have become more multi-disciplinary and holistic in nature. The departments involved cover issues such as social welfare, women and child development, housing, small and micro credit, health, education, self-help groups and export promotion. Because of growing use of technology and changes in the world of work, labour administration cannot exist in isolation. In certain cases, a Group of Ministers (GoM) have been formed to carry out coordination among the different Departments/Ministries with responsibilities relating to labour issues. For example, there is a GoM with respect to the drafting of national employment policy at the level of Central government. At the State level, in West Bengal there is a GoM to deal with industrial relation matters pertaining to the jute industry.

In recent times the focus of labour administration has shifted towards ensuring 'ease of doing business'. The objective of ease of doing business is to ensure an investment friendly business atmosphere where implementation of labour legislation takes a back seat. Industrial units and firms are being granted immunity from compliance with certain labour laws. Self-declaration of compliance by employers has become the standard operating procedure and there is a general bar on carrying out proactive inspections initiated by labour inspectors. Inspection schedules are instead computer-generated and based on random selection. Granting of licences and permits are being put under legally guaranteed time deadlines within the general public services administration in a citizen-client mode. Licences are being granted based on self-declared information without their validity being checked by physical inspection.

\subsection{INTRODUCTION OF NEW TECHNOLOGY}

The main challenge confronting labour administration bodies is how to use new technology to enhance the effectiveness and efficiency of their operations. Use of new technology is still in its early stages but labour administration 
needs to be able to handle a huge volume of data, particularly with respect to work in the informal sector. Also, with regards to provision of welfare and social security measures, labour administration needs to disburse a large amount of money within a specific timeframe. This is not possible without using new technology, but at the same time there is a need to develop a system based on planning and provision of physical and human infrastructure. So far, the measures adopted have been piecemeal in nature and responses have been impulsive rather than constituting a well-thought out plan. For example, in West Bengal, there has been computerization and digitization of various social security schemes, but there are many problems. The main problem faced by the labour administration in this regard is imputing the huge amount of information relating to workers who registered with social security schemes prior to digitalization. Also, there are technical issues, such as whether the present infrastructure would be able to handle the growing number of beneficiaries in the future. Online activities regularly face internet speed issues and inter-office connectivity is still a big bottleneck. Use of new technology for inter- and intra-office communication is still in its preliminary stage and needs to develop. The e-office remains far from being realized at both the Central and State levels.

\subsection{CONCLUSIONS}

Labour administration in India is grappling with changes in the world of work. It is trying to find a middle way in an era of globalization where de-regulation coexists with protection of basic labour rights. Workspaces are undergoing significant transformations, making traditional administrative structures less relevant. There has been growing informalization of the Indian labour force during the past 25 years and among the informal sector workers there are large number of self-employed persons who are engaged in petty activities and who form a vast reserve army in the labour market. Even for wage employment, there has been quite a bit ambiguity as far as employer-employee relations are concerned because of the existence of layers of intermediaries between principal employers and employees. As a consequence, many employees are uncertain about who they work for. Overall, there has been a substantial dismantling of employer-employee relationships during the last two decades. This creates difficulties for the application of labour regulations since most labour laws and similar regulations are based on the presumption that an employment relationship exists. The basis of labour regulation has therefore been severely challenged.

Greater compliance with certain Acts, such as the Minimum Wages Act 1948, would benefit both formal and informal sector workers. This is particularly true with respect to the large number of agricultural workers for whom no 
other labour legislation protections are available. A more universal application of the Employee's Provident Fund \& Miscellaneous Act and Employees' State Insurance Act would provide social security coverage to a significant number of workers in the informal sector. The introduction of a minimum pension of Rs 1,000 under the EPF \& Misc. Act in 2010 represents a very useful step towards achieving this objective.

Trade union membership is on the decline and traditional trade unions are finding it difficult to mobilize workers against exploitative practices. The weakening of trade union bargaining power has resulted in social dialogue and tripartite consultation losing their vitality and becoming a formality in many instances. Attempts have been made in some States to make unionization a difficult task and while traditional trade unions have recently started mobilizing informal sector workers, they are finding this an increasingly challenging task. Mobilization of workers in domestic spaces is particularly difficult for traditional trade unions, which still consider factory and organized spaces of manufacturing as the space where workers' mobilization takes place.

Flexibility and also redistribution have been facilitated by institutionalizing employment-specific (and primarily tripartite) welfare boards. In some sectors, such as construction, the board collects cess from the employers, but otherwise States finance the cost of providing benefits. The issue here is that as States take over the responsibility of providing social security benefits to informal sector workers, the relationship between the employers and employees becomes further obscured. A better approach would be to require that employers finance the statutory social security benefits, since they appropriate the products generated by the workers. The role of States should be restricted to cases where employer-employee relationships are completely absent.

Labour administration in India has become more decentralized and technology is being used to reach out to individual workers in a more effective manner. Activities have become more broad-based and inclusive. The functions of labour administration are no longer restricted to traditional functions but have spread to encompass home-based workers and the self-employed and also the facilitation of welfare and social security. Labour administration is also trying to maintain its position as an integral organ within the general public administration and as an institution is still preserving the culture of tripartite consultation and social dialogue. A majority of labour administration bodies are tripartite in nature and policy making is predominantly through social dialogue.

In the recent past, keeping in mind the United Nations' (UN) 11 Principles of Effective Governance for sustainable development, certain initiatives have been taken to comply with the objectives of effectiveness, accountability and inclusiveness. Effectiveness and accountability go together and labour administration both at the Central and State levels has made efforts to improve both. 
Specific steps have included ensuring timely delivery of services, improving accountability, enabling online processing of registrations and licences, facilitating the uploading of inspection reports online, strengthening labour tribunals and labour courts, amending provisions to make them relevant to changed circumstances, introducing a 24-hour helpline, measures to ensure timely disposal of grievances, and the introduction of special provisions for individual dismissal cases. A major initiative is presently being undertaken to rationalize and simplify a large number of labour laws and consolidate them into four codes, namely, wages, social security, industrial relation and occupational health, safety and welfare. To make labour administration more inclusive, attempts have been made to formulate broad-based welfare and social security schemes to include informal sector workers who were previously outside protective legislative provisions. Overall, it is evident that steps are being taken to make labour administration more effective, accountable and inclusive, in keeping with the UN's Sustainable Development Goals.

There is a need to initiate social dialogue among the stakeholders to continue generating awareness among workers and informal sector workers in particular. Cooperation from all the stakeholders is crucial with respect to successful implementation of labour legislation and social security schemes. States alone cannot ensure these schemes assist the targeted beneficiaries. Active cooperation from trade unions, employers and larger civil society is needed for successful inclusion of informal sector workers. ${ }^{6}$ States need to identify social partners at grassroot levels and involve them in the process of amalgamating informal sector workers into the fold of social protection. The role of social dialogue in building consensus is presently being underutilized in the sense that too much emphasis is placed on tripartite consultation involving registered trade unions and employers' association along with State labour administration. Including NGOs and civil society organizations in the tripartite consultations would potentially be of value, given that these organizations work very closely with workers in the informal sector.

\section{NOTES}

1. For example, retrenchment of workers and closure of units require prior permission of the State for companies employing more than 100 workers.

2. Head loaders are workers who are engaged in manual labour involving physically moving articles from one place to another and sometimes carrying things on their head.

3. There are social security boards for various employment types like construction, transport, domestic, brick-making units and so on. These boards are autonomous in nature and tripartite in character in the sense that board members are drawn by having equal representation from employers, trade unions and the State. Even though these boards are autonomous in nature and formulates its own strategies to 
include informal sector workers within the welfare umbrella of the State, labour administration plays an important role in the constitution and functioning of these boards. The basic structure is tripartite and these boards meet at periodic intervals to formulate policy, with the labour administration setting the agenda.

4. Block is the administrative unit at the bottom of the hierarchy. A State is divided into districts, districts into sub-divisions and sub-divisions into blocks. Blocks consist of villages.

5. Debasish Bhattacherjee (2001) argues that the evolution of industrial relations has been incremental and adaptive and the dominant role of the State may be a necessity given the complexity of the labour market.

6. Durbar in West Bengal and Civic in Karnataka are successful examples of civil society interventions that have made a difference.

\section{BIBLIOGRAPHY}

Alessandrini, M. (2019), 'Jobless Growth in Indian Manufacturing: A Kaldorian Approach', accessed 31 January 2019 at https://www.researchgate.net/publication/ 255611152.

Bhattacherjee, D. (2001), 'The Evolution of Indian Industrial Relations: A Comparative Perspective', Industrial Relations Journal, 32 (3), 244-63.

Breman, J. (1995), 'Labour, Get Lost: A Late-Capitalist Manifesto', Economic and Political Weekly, 16 September.

Chakraborty, A. (2015), 'Revisiting the Futility Thesis: Reforming Labour Markets in India', Economic \& Political Weekly, 50 (20), 16 May.

Dhal, M. (2018), 'Trade Union Strategy and Responses to Changes in Employment Structure and Forms in India', Japan Labor Issues, 2 (8), August-September.

Casale G. and Sivananthiran A. (2015), Labour Administration and Labour Inspection in Asian Countries: Strategic Approaches, ILO, Geneva.

Government of India (1969), Report of the National Commission on Labour (1st), Ministry of Labour \& Employment, New Delhi: Government of India.

Government of India (2002), Report of the National Commission on Labour (2nd), Ministry of Labour \& Employment, New Delhi: Government of India.

Government of India (2015), Unemployment Employment Survey 2013-14, Labour Bureau, Ministry of Labour \& Employment, New Delhi: Government of India.

Government of Karnataka (2015), Annual Report 2014, Bangalore.

Government of West Bengal (2015), Labour in West Bengal 2014, Kolkata.

Heyes J. and Rychly L. (eds) (2013) Labour Administration in Uncertain Times, Policy, Practice and Institutions, Cheltenham, UK and Northampton, MA, USA: Edward Elgar and Geneva: ILO.

ILO (1997), Industrial Relations, Democracy and Social Stability, World Labour Report 1997-98, Geneva: ILO.

ILO (2011), Labour Administration and Labour Inspection, Report V, International Labour Conference, 100th session, Geneva.

Manohar, L. (2005), 'Labour Administration and the Informal Economy in India', in A. Sivananthiran and C.S. Ventata Ratnam (eds), Informal Economy: The Growing Challenge for Labour Administration, ILO: New Delhi, pp. 43-74.

Leisink, P. (1999) (ed.), Globalization and Labour Relations, Cheltenham, UK and Northampton, MA, USA: Edward Elgar. 
Mamkoottam, K. (2003), Labour and Change: Essays on Globalization, Technological Change and Labour in India, New Delhi: Response (A Division of Sage).

Mehrotra Santosh et al. (2012), 'Joblessness and Informalization: Challenges to Inclusive Growth in India', IAMR Occasional Paper No. 9/2012, Planning Commission, Government of India, Delhi.

Ministry of Labour \& Employment, Government of India (2015), Annual Report 2014, New Delhi.

Papola, T.S. and Pais, J. (2007), 'Debate on Labour Market Reforms in India, a Case of Misplaced Focus', Indian Journal of Labour Economics, 50 (2), 183-200.

Patil, B.R. (1998), 'A Contemporary Industrial Relations Scenario in India with Reference to Karnataka', Indian Journal of Industrial Relations, 33 (3), 289-312.

Rajeev, M. (2010), 'Contract Labour Act in India: A Pragmatic View', International Journal of Economic Policy in Emerging Economies, 3 (3), 237-52.

Rychly, L. (2013) 'Ministries of Labour: Comparative Overview. Database, Organograms', ILO Action, LAB/ADMIN, Working Document No. 27, ILO, Geneva.

Saini, D.S. (1991), 'Compulsory Adjudication of Industrial Disputes: Juridificaton of Industrial Relations', Indian Journal of Industrial Relations, 27 (1), 1-18.

Saini, D.S. (2003), 'Labour Organization and Labour Relations Law in India', in Lucy Williams, Peter Robson and Absjorn Kjonstad (eds), Law and Poverty: Poverty Reduction and the Role of the Legal System, London: Zed Books.

Saini, D.S. and Sami K.A. (eds) (2000), Human Resource Management: Perspectives for the New Era, New Delhi: Response Books (A Division of Sage).

Sarkar K. (2016), 'Enhancing Labour Administration's Performance in India', NLI Research Study Series, 118/2016, VVGNLI, Noida, India.

Sarkar, K. (2018), 'Do Construction Workers have access to social security provisions', Abstract of Papers of 61st Annual Conference of Indian Society of Labour Economics, Mumbai.

Sen Gupta, A.K. (2003), 'Decline of Trade Union Power in India', The Indian Journal of Labour Economics, 46 (4), 685-701.

Sen Gupta, A.K. and Sett, P.K. (2000), 'Industrial Relation Law, Employment Security and Collective Bargaining in India: Myths, Realities and Hopes'. Industrial Relations Journal, 31 (2), 114-53.

Singh, C., Sanyal, A. and Bharati, K. (2015), 'Social Security Schemes: A Case for Universalisation', Indian Institute Management Bangalore, Working Paper N0. 498, Bangalore, India.

Srivastava, D.K. (2006), 'Trade Union Response to Declining Membership Base: Best Practices from Mumbai Based Trade Unions', Indian Journal of Industrial Relations, 41 (4), 355-74.

Thakur, C.P. (2003), 'Emerging Pattern of Industrial Relations', The Indian Journal of Labour Economics, 46 (4), 637-49.

Vatsa, V. (2005), 'Strategies for Enhancing the Role of Labour Ministry in the Informal Economy', in A. Sivananthiran and C.S. Ventata Ratnam (eds), Informal Economy: The Growing Challenge for Labour Administration, ILO: New Delhi, pp. 75-106.

Ventakanarayan, M. and Suresh, N.V. (2013), 'Growth \& Structure of Workforce in India', MPRA Paper, XXI (52), accessed 30 January 2019 at https://mpra.ub.uni -muenchen.de/id/eprint/48003.

Venkata Ratnam, C.S. (2001), Globalization and Labour-Management Relations: Dynamics of Change, New Delhi: Response (A Division of Sage Publications). 
Venkata Ratnam, C.S. (2003), Negotiated Change: Collective Bargaining, Liberalization and Restructuring in India, New Delhi: Response (A Division of Sage Publications).

Venkata Ratnam, C.S. and Varma A. (ed.) (1998), Challenge of Change - Industrial Relations in Indian Industry, New Delhi: Allied Publishing.

World Bank (1995), Workers in an Integrated World, World Bank Development Report 1995, New York: Oxford University Press. 